\title{
Analysis of Students' Academic Anxiety Through Personality Prediction in Counseling Practice
}

\author{
Kusnarto Kurniawan \\ Department of Guidance and Counselling \\ Universitas Negeri Semarang, Indonesia \\ kusnarto@mail.unnes.ac.id
}

\section{Mulawarman}

Department of Guidance and Counselling

Universitas Negeri Semarang, Indonesia

mulawarman@mail.unnes.ac.id

\author{
Zakki Nurul Amin \\ Department of Guidance and Counselling \\ Universitas Negeri Semarang, Indonesia \\ zakki.nurul.amin@mail.unnes.ac.id
}

\author{
Suharso \\ Department of Guidance and Counselling \\ Universitas Negeri Semarang, Indonesia \\ suharso@mail.unnes.ac.id
}

\author{
Eko Nusantoro \\ Department of Guidance and Counselling \\ Universitas Negeri Semarang, Indonesia \\ kajurbk@mail.unnes.ac.id
}

\begin{abstract}
Many factors are related to students' academic anxiety when learning in class. This research is based on the phenomenon of some students who have difficulty and anxiety in counseling practice classes. The focus of this study is to predict students' academic anxiety based on their personality traits. Ten Item Personality Inventory (TIPI) and Academic Test Anxiety (ATA) was administered to 103 counselors-in-training and analyzed using multiple regression. The results showed that only Extraversion $(\beta=-0.21, p<0.05)$ and Emotional Stability $(\beta=-$ $0.33, \mathrm{p}<0.01)$ were negative and significant predictors of student academic anxiety when counseling practice. This findings have implications to understanding personalities that are important for supporting professional development counselors.
\end{abstract}

Keywords: personality, student's academic anxiety, counselor-in-training, counseling practice

\section{INTRODUCTION}

Counseling is a professional service activity carried out by trained counselors. To conduct professional practice their needs specific and comprehensive competencies [1, 2]. Some studies show the importance of counselors having professional skills when helping clients [3]. A counselor should have basic skills, various counseling techniques, and be able to apply counseling theory when conducting their professional practice [4]. In this case, the counselor has gone through the process of education, experience, and practice that has been professionally studied [5].

Providing practical experience is an important part of the counselor's education program [6]. Through counseling practices, students or counselors-in-training will have direct experience to help counselees [7]. So, they need to get adequate counseling practice experience, one of which they get on counseling practice class. But in other hand, the phenomenon is counselor's skills do not increase through training or experience [8]. Counseling practice are considered difficult for students. They often feel anxious when practicing counseling.

Anxiety while doing academic process known as academic anxiety [9]. Academic anxiety is a condition that results from excessive anxiety with various academic tasks in an educational institution [10]. High anxiety will negatively affect performance. Students who experience psychological distress, make them uncomfortable in class, not enthusiastic about learning, get poor learning outcomes, and more attitude avoidance of assignments. This is caused by decreased attention, concentration and memory in students.

Symptoms of affective academic anxiety include feelings of annoyance due to subject difficulties, feelings of pessimism, and irritability [11]. While physical symptoms that appear include reduced appetite, difficulty sleeping, difficulty concentrating, back pain, migraines, tense eyes, thrush, stomach ache, and trembling while practicing counseling. In addition, behavioral disorders that arise, such as they refuse when asked to give examples, are reluctant to argue during class, and also delay the collection of assignments.

Likewise, when students have academic anxiety when practicing counseling, they will experience problems affective, physical, and behavioral. For counselor-intraining students, personality is also related to personal quality as an important factor that supports the success of the counseling process [13]. So as to support more effective counseling practices, there needs to be an understanding of student personality related to academic anxiety [12]. There are indeed many factors associated with academic anxiety, but this study focuses on the contribution of personality to students' academic anxiety when counseling practice. An understanding of personality and academic anxiety is important to support the personal development of professional counselors. 
Identifying the right model to explore students academic anxiety in relation to their personalities is an important task. Personality models that are developed based on specific factors can be suitable for academic anxiety research and these models need to be the basis for analyzing and reducing academic anxiety related to personality factors [12].

Indeed, personality is a complex psychological structure and includes a countless set of traits with different effects on the body and mind [13]. One of the most known personality theories is the theory of the five personality factors known as the big five personality traits. Chamorro et al [15] suggested that academic anxiety among students can be explored by both of disposition and personality determinants of their use Big Five Factors.

Factors in big five personality theory are [12]: (1) emotional stability (low in neuroticism), a long-term tendency to be in a stable emotional state (calm, comfortable, and happy); (2) extraversion, this shows how outgoing and social someone is. a person enjoys being with people, participating in social gatherings, and is full of energy; (3) openness, this is a holistic concept characterized by an emphasis on transparency and free, unlimited access to knowledge and information, as well as collaborative or cooperative management and decision making rather than central authority; (4) agreeableness (adjustment), this reflects social and prosaically orientation and can be said to be the opposite of hostility towards others. it is considered as kind, sympathetic, cooperative, warm, caring, trustworthy, and humble; and (5) conscientiousness, this implies a desire to do a good job. This illustrates the power to control impulses as they are accepted in society (Table 1). It facilitates tasks and goaloriented behavior.

The theory of five major factors is considered to be the most prominent for exploring students' personalities in academic settings [16]. Ozer and Benet [17] also revealed that psychological research aimed at the student population must consider five great traits because it has been associated with a variety of behaviors. Therefore, five personality factors were considered to predict academic anxiety among students in this study.

Table 1

Correlation Matrix Between Personality Traits and Academic Anxiety

\begin{tabular}{|c|c|c|c|c|c|c|c|c|}
\hline Variables & Mean & SD & 1 & 2 & 3 & 4 & 5 & 6 \\
\hline 1. $\quad$ Extraversion $(\mathrm{E})$ & 9.81 & 2.25 & - & & & & & \\
\hline 2. Agreeableness (A) & 9.80 & 1.62 & 0.07 & - & & & & \\
\hline 3. Conscientiousness (C) & 10.85 & 1.93 & 0.01 & 0.15 & - & & & \\
\hline 4. Emotional Stability (ES) & 8.97 & 2.17 & 0.16 & 0.14 & 0.18 & - & & \\
\hline 5. Openness to Experience (O) & 9.80 & 1.95 & $0.23 *$ & 0.05 & $0.30 * *$ & 0.19 & - & \\
\hline 6. Academic Anxiety & 12.41 & 72.11 & $-0.27 * *$ & -0.03 & -0.10 & $-0.37 * *$ & -0.14 & \\
\hline
\end{tabular}

\section{A. Procedure and participant}

\section{METHODS}

The research design used in this study is a correlational research design. Subjects in this study amounted to 102 students or counselor-in-training that follows the course of counseling practice. Sample of respondents aged between 20 and 23 years, with an average age of 20.7 years. For those who agree to participate in this study, will fill the instruments prepared by the researchers. Data is collected directly during field practice debriefing activities.

\section{B. Instrument}

The current research used back translation procedure before the data retrieval process. In order to validate the Indonesian versions of the Ten-Item Personality Inventory (TIPI) and Academic Test Anxiety (ATA), the questionnaires were translated from English into Indonesian.

The translated items, back-translation of the items into English and comparison of the back translation and original questionnaire to inform a final optimum version in Indonesian. The process of back translate instruments was carried out by the language institution of the state university of Semarang.

Ten-Item Personality Inventory (TIPI) developed by Gosling, Rentfrow, and Swann [18] which consists of 10 items to reveal personality trends in accordance with the big five personality theory. Respondents were asked to choose from 7 categories of answers ranging from strongly disagree to strongly agree. An example of an item in this instrument is "I see myself as: Extraverted, enthusiastic" back translate into "Saya melihat diri saya sebagai pribadi yang: Terbuka, antusias". The validity of the instrument uses product moment $\mathrm{r}$ scores with ranges ( 0.531 to 0.632 ), and the reliability of the instrument using the Cronbach's Alpha calculation gets the results $\mathrm{r}=$ 0,572 .

Academic Test Anxiety (ATA) developed by Pintrich [10] to measure a person's anxiety level in fulfilling academic tasks and activities. This instrument consists of 5 items. An example of an item on this instrument is " $i$ have an uneasy, upset feeling when $i$ take exam" back translated and modified into "Saya merasa tidak nyaman dan gelisah saat mengikuti mata kuliah praktik model-model konseling". The validity of the instrument using the product moment range $\mathrm{r}$ score $(0.541$ to 0.745$)$, and the reliability of the instrument using the Cronbach's Alpha calculation obtained the result $\mathrm{r}=$ 0.657 .

\section{Data analysis}

Assessing the correlation between the variables, we used Pearson correlation coefficient. Whereas, multiple linear regression analysis was used to answer research problems and find out the prediction of personality traits to students' academic anxiety. Processing data in this study will be carried out using the SPSS 21.00 program for Windows. 


\section{RESULT}

\section{A. Preliminary Analysis}

Mean, standard deviation, and zero-order correlations are shown in table 1 . Not all personality types have a significant relationship with students' academic anxiety. Only Extraversion $(r=-0.27, p<0.01)$ and also Emotional Stability $(r=-0.37, p<0.01)$ which have negative and significant correlation with academic anxiety. Also, a positive significant relationship was found between the conscientiousness with openness to experience $(\mathrm{r}=0.30 ; \mathrm{p}<0.01)$.

\section{B. Multiple Linear Regresion}

In the next step, the simultaneous regression was used to study the prediction of students' academic anxiety by personality traits. Table 2 shows the results of multiple linear regression analysis between personality types on students' academic anxiety. According to Table 2, all the predictor variables have a significant effect on students' academic anxiety $(\mathrm{F}=4.28 ; \mathrm{p}<0.01)$.

The results show that only Extraversion $(\beta=-0.21 ; p$ $<0.05)$ and Emotional Stability $(\beta=-0.33 ; \mathrm{p}<0.01)$ predict students' academic anxiety when counseling practice. Note that all the predictor variables presented $18 \%$ of variance of students' academic anxiety.

Table 2

Predicting Academic Anxiety Based on Personality Traits

\begin{tabular}{|c|c|c|c|c|c|c|c|c|}
\hline Predictor Variables & $\begin{array}{l}\text { Criterion } \\
\text { Variable }\end{array}$ & $\mathbf{F}$ & $\mathbf{P}$ & $\mathbf{R}$ & $\mathbf{R}^{2}$ & $\boldsymbol{\beta}$ & $\mathbf{t}$ & $\mathbf{P}$ \\
\hline $\begin{array}{l}\text { Extraversion (E) } \\
\text { Agreeableness (A) } \\
\text { Conscientiousness (C) } \\
\text { Emotional Stability (ES) } \\
\text { Openness to Experience (O) }\end{array}$ & $\begin{array}{c}\text { Academic } \\
\text { Anxiety }\end{array}$ & 4.28 & 0.001 & 0.43 & 0.18 & $\begin{array}{r}-0.19 \\
0.04 \\
-0.04 \\
-0.32 \\
-0.03\end{array}$ & $\begin{array}{r}-2.16 \\
0.35 \\
-0.32 \\
-3.42 \\
-0.25\end{array}$ & $\begin{array}{c}0.03^{*} \\
0.73 \\
0.74 \\
0.00^{* *} \\
0.80\end{array}$ \\
\hline
\end{tabular}

Notes:

$\beta$, Beta coefficient; F, F-test; t, t-test; P, Significant Level; R, Regression Coefficient; R2, Determination Coefficient**Coefficients are significant at 0.01 level *Coefficients are significant at 0.05 level

\section{DISCUSSION}

An important aspect for a counselor is a professional identity that is integrated with professionalism, values, theories and techniques. As a professional who must integrate personal identity by profession, a counselor should be able to adopt the skills, values, roles, attitudes, etiquette, ways of thinking, and problem-solving pattern [19]. Therefore, counseling practice training must be carried out effectively to improve student or counselor-intraining skills.

The results of this study indicate that a person's personality traits can predict students' academic anxiety. In particular, a person with a personality traits Extraversion and Emotional Stability also can reduce their academic anxiety while practicing counseling. Feelings of anxiety increases when they face obstacles when counseling practice can be minimized openly with others, and also control emotions [20].

Extraversion is one of the five personality traits of the Big Five personality theory. It indicates how outgoing and social a person is. A person who scores high in extraversion they enjoy being with people, participating in social activity, and are full of energy [21]. When someone enjoys being together with other students in the class, participating in class actively, and full of energy, it is proven to reduce academic anxiety when counseling practice. That is because positive attitudes towards other groups can support well-being and reduce anxiety [22, 23].

In line with a practical counseling that include the social skills, person with high extraversion is outgoing and enthusiastic. Because individuals high in extraversion have a tendency to seek out the company and stimulation of other people. They enjoy engaging with the external world. These individuals thrive on excitement, and are enthusiastic, action-oriented people. They like to be the center of attention in groups.

On the other side are students with introverts at counseling practice. These students have less excitement and energy than other students. They are less involved in class discussions, including counseling practices, and tend to be quiet and look after themselves. Therefore, lecturers need to pay attention to introverted students, and try to get them involved and engagement in class [24, 25].

While emotional stability refers to a person's ability to remain stable and balanced. People with high emotional stability (low neuroticism) are less emotional and less irritable. They tend to be emotionally stable, calm, and not constantly experiencing negative feelings. This personality is needed for counselors, including students or counselorin-training, when practicing counseling. Brammer [14, 26] explains that emotional stability supports the personal quality of the counselor, which when someone has emotional stability, they are more able to control themselves positively.

On the other hand, students with neuroticism will easily experience academic anxiety when practicing counseling. They are not comfortable with the demands and tasks in counseling practice class. As an important subject for prospective counselors, counseling practice classes are not only theory, but directly practice counseling skills and techniques to help counselees [27]. So based on these findings, the lecturer needs to create a comfortable and pleasant atmosphere, including arranging assignments and learning content to make students happy in the counseling practice class.

\section{IMITATION AND IMPLICATIONS}

This study successfully clarified the correlation between personality traits and students' academic anxiety when counseling practices. The findings of this study specifically show that only extraversion and emotional stability negatively and significantly predict students' academic anxiety.

However, current research has several limitations. First, in this study academic anxiety was predicted only by personality traits, while other variables related to anxiety 
were not controlled in this study. Therefore, further studies need to be done by predicting other variables that are predictors of academic anxiety. Second, this research uses correlation studies so an experimental study is needed to develop students 'personal or counselor-in-training and reduce students' academic anxiety when counseling practice.

There are two practical implications from this finding. First, lecturers need to consider and understand students' personality traits during counseling practice so that students do not experience academic anxiety. Second, students need to be equipped with their main personality development to be more extraversion and emotionally stable through soft skills training.

\section{REFERENCES}

[1] N. M. Ishak., S. Amat, \& A. Y. A. Bakar, "Counseling Professional Ethics From Viewpoint Of Counselor Educators". Journal of Educational Psychology \& Counseling, Volume 5 March 2012, Pages 71-80.

[2] S. Lester, "Professional standards, competence and capability". Higher Education, Skills and Work-based Learning 4 (1), pp31-43, 2014

[3] S. Cormier \& H. Hackney, Counseling strategies and interventions. 7 ed.; Boston: Pearson Education Inc, 2008.

[4] N. E. Yaumas, et all. "The importance of counselling basic skills for the counsellors", International Journal of Pure and Applied Mathematics Volume 119 No. 18 2018, 1195-1207

[5] W. B. Pafilo. Art based therapy in the treatment of eating disorder. Eating disorder. 2005, 12.

[6] Mulawarman, Muslikah, E.P. Nugraheni, S. Hariyadi, and Z. N. Amin, "Peningkatan keterampilan dasar konseling berbasis nilai humanis melalui teknik oars bagi konselor pendidikan/guru BK di SMA Kota Salatiga", SNK-PPM vol 1, pp. 164-167, Desember 2018, Seminar Nasional Kolaborasi Pengabdian Masyarakat.

[7] R. F. Reese, J.S. Young, and G. A. Hutchinson. Preparing counselors-in-training for private practice: a course in clinical entrepreneurship. The Professional Counselor, Volume 3, Issue 1, 2013, Pages 23-33.

[8] H. L. Hackney. Development of a Pre-practicum Counseling Skills Model. 2011, 11 (2).

[9] P. Vitasari, et all. The relationship between study anxiety and academic performance among engineering students. Procedia social and behavioral sciences 8 (2010) 490-49, International Conference on Mathematics Education Research 2010 (ICMER 2010)

[10] Pintrich, P., Smith, D., Garcia, T., \& McKeachie, W.J. A manual of the use of the motivated strategies for learning questionnaire (MSLQ). 1991.

[11] G. Serafini, P. A. Geoffroy, A. Aguglia, G. Adavastro, G. Canepa, M.Pompili \& M.Amore. Irritable temperament and lifetime psychotic symptoms as predictors of anxiety symptoms in bipolar disorder, Nordic Journal of Psychiatry, 2018. 72:1, 63-71.

[12] S. Kumaran \& K. Subramanian. Personality and Test Anxiety of School Students. International Journal of Education and Psychological Research (IJEPR), 22015, Volume 4, Issue 2.
[13] R. Abasi-Asl, H. Naderi, and A. Akbari. "Predicting female students' social anxiety based on their personality traits", Journal of Fundamentals of Mental Health 2016 Nov-Dec; 18(6): 343-9

[14] Z. N. Amin, Mulawarman, E.P. Nugraheni, adn Carti, "Counsellors' personal quality in public senior high school", Advances in Economics, Business and Management Research, volume 14 pp.444-448, 2016. Proceeding of 6th International Conference on Educational, Management, Administration and Leadership (ICEMAL).

[15] T. Chamorro-Premuzic, G. Ahmetoglu, and Furnham. "Little more than personality: Dispositional determinants of test anxiety", Learning and Individual Differences, 2018,18, 258-263.

[16] M.C. O'Connor and S. V. Paunonen. "Big Five personality predictors of post-secondary academic performance", Personality and Individual Differences, 2007, 43, 971-990.

[17] D. J. Ozer and V. Benet-Martinez. "Personality and the prediction of consequential outcomes", Annual Review of Psychology, 2005, 57, 401- 421.

[18] Gosling, S. D., Rentfrow, P. J., and Swann, W. B., Jr. "A Very Brief. Measure of the Big Five Personality Domains", 2003. Journal of Research.

[19] M. D, Gibson, C.T. Dollarhide, and J.M. Moss. "Professional identity development: A grounded theory of transformational tasks of new counselors", Counselor Education and Supervision 2010, 50, 21-37.

[20] J. J. Frederickson, I. Messina, and A. Grecucci. "Dysregulated anxiety and dysregulating defenses: toward an emotion regulation informed dynamic psychotherapy", Front Psychol. 2018; 9: 2054

[21] O. Irengun \& S. Ankboga, "The effect of personality traits on social entrepreneurship intentions: a field research", July 2015. Procedia - Social and Behavioral Sciences 195:1186-119

[22] A. Andriyani, A. Himma, S. Alizar, Z.N. Amin, and Mulawarman., "The relationship of anxiety, school burnout and well-being in high school students", Advances in Social Science, Education and Humanities Research (ASSEHR), volume 158, pp. 130-135, Proceedings of the International Conference on Teacher Training and Education 2017 (ICTTE 2017).

[23] Z.N. Amin, M.E. Wibowo, L. Loekmono, S. Hariyadi, and B. Isrofin, "Ethnic identity and other-group orientation on Javanese and Chinese students", ASSEHR, volume 158, pp. 875-880, Proceedings of the International Conference on Teacher Training and Education 2017 (ICTTE 2017).

[24] Muslikah, S. Hariyadi, and Z.N Amin, "Pengembangan model peer counseling sebagai media pengalaman praktik konseling", Indonesian Journal of Guidance and Counseling: Theory and Application, 5(3), 48-52, 2016.

[25] D.Y.P. Sugiharto, S. Hariyadi, Z.N. Amin, Mulawarman, Muslikah, and E.P. Nugraheni, "Pengembangan kompetensi konselor melalui pelatihan konseling motivational interviewing (mi) berbasis local wisdom budaya Jawa", Vol. 1, No. 2, Februari 2019, Caradde: jurnal pengabdian kepada masyarakat.

[26] Z.N. Amin, "Kualitas pribadi konselor", unpublished.

[27] Z.N. Amin, "Portofolio teknik-teknik konseling (teori dan contoh aplikasi penerapan)", unpublished. 